\title{
The illustration as a landscape of memory. The graphic work of Lima de Freitas, 1946-1993
}

abstract The plurality of the artistic universe and the history of graphic design, illustration and drawing in Portugal between 1940 - a year where two strong artistic currents arise: neo-realism and surrealism - and 1974 - a changing year in our history - encounter in José Maria Lima de Freitas's (1927-1998) works the paradigmatic time and ways where many artists, coming from a neo-realism generation, evolve different paths, in particular surrealism, as the author. This paper's purpose is to introduce Lima de Freitas and his artistic path focusing on his work as a Portuguese illustrator. This activity that he practiced, developed and perfected over thirty years in the XX ${ }^{\text {th }}$ century, enlightening with expertise some of the greatest and most remarkable Portuguese and foreign writers. He was able to adapt and interpret expressively each author, always finding the perfect insertion in the writing of different periods of time and respective creators. Due to the multiplicity of Lima de Freitas's legacy, the books with his drawings have been catalogued, a bibliographical inventory that unites the most significant images for each of his illustrated works, allowing to recognize the polygraphy where can be found the fundamental thread of his work as an image thinker.

keywords design culture, illustration, drawing, memory, artistic studies

\section{Introduction}

As a painter, graphic artist, designer and playwright José Maria Lima de Freitas has left us an important polygraph legacy, which reflects a tireless thinker and creator of images. However, as pointed out by Fernando António Baptista Pereira' in the introduction to the work of Lima de Freitas, 50 Years of Painting, "a rich critique of the vast, multifaceted and transverse work of Lima de Freitas" has been "unjustifiably poor if we compare it with what has been dedicated to some friends of his generation". Indeed, although mentioned by several art historians and other scholars throughout the second half of the $X X^{\text {th }}$ century, such as by Ernesto de Sousa, in a volume of the Contemporary Art Collection (1961), by José-Augusto França in The Art in Portugal in the XX $X^{\text {th }}$ Century (1985), by Rui Mário Gonçalves in History of Art in Portugal (1986) or by Fernando Rosas, History of Portugal (1994), Lima de Freitas has often been cited in little depth or inserted in extended analysis of other contemporary artists. Only two authors have revealed a specific interest in studying the career of this artist: the philosopher and anthropologist Gilbert Durand, who published Mitolusismos Lima de Freitas (1987) and Baptista Pereira,

' Fernando António Baptista Pereira, (1953) Art Historian and professor in Faculdade de Belas Artes da Universidade de Lisboa. 
with the work Lima de Freitas, 50 Years of Painting (published in 1997); and Lima de Freitas, Retrospective 1946-1984 (1984). In order to understand the unfortunate critiques directed at the author under study, all the periodicals of time where art critiques, intellectuals and artists gave their contributions, are being collected. The same data collection is being done for all the articles that mention Lima de Freitas. Based on the still ongoing analysis, in most cases the author is cited as an artist with exposed works or small analysis to his work is made, mainly on his preference for illustrations and drawings over painting. It is also important to mention that Lima de Freitas spent several periods outside Portugal and his absence clearly contributed for a minor recognition among his colleagues. In working on a critical and comparative analysis between authors and currents from the social, political and cultural framework present in the second half of the XX Century, we aim to identify a pattern that contributes to the understanding of different visual expressions in term of Lima de Freitas' illustration and drawings.

\section{An artist, his work and his paths}

José Maria Lima de Freitas stood out as a painter and writer, but was also a remarkable graphic artist and a word illustrator. In search of a significant work of visual Portuguese culture in the scope of the design and illustration during the second half of the $\mathrm{XX}^{\text {th }}$ Century, he imposed his figure, starting a study of a monographic nature primarily intended to identify his contributions to the affirmation of graphic design in Portugal. In a troubled time caused by the Spanish Civil War and the Second World War, Portugal was a country living in dictatorship, with a thirst for freedom, ansious for denouncing social injustice and defending the human dignity, strengthening ties between the writers and artists, and revealing this relationship in their work, both aesthetic level as the politicalideological level. Works of literature as Redol Alves, Manuel da Fonseca, Mario Dionisio, Carlos Oliveira, Fernando Namora, Anthony Charlton, Sebastian Rodrigues and Pereira Gomes Soeiro appear illustrated by artists like Lima de Freitas, Júlio Pomar, Manuel Ribeiro of Pavia, Victor Palla, Cipriano Gold, Antonio Domingues, Vespeira, Alice Jorge Dias Coelho, Augusto Gomes or Rogério Ribeiro inaugurating, admittedly, the neorealist current.

It was also the presence of Candido Portinari (1903-1962), a brazilian painter, in the Portuguese World Exhibition in 1940, who has presented Café (1935) in the Pavilion of Brazil - revealing the conditions of the exploitation of coffee workers - as well as the Mexican art muralists, Diego Rivera (1886-1957) and José Orozco (1883-1949), Clearly, this artists influenced and served as an example to the young Portuguese painters. In Portugal, the painting Almoço do Trolha (1946) by Júlio Pomar, proved to be an essential reference of neo-realism in our country. The artists of neo-realism explicitly placed themselves on the people side and their ideological position, showing the misery, suffering, subjugation and the work of the lower classes, while fighting the geometric abstraction.

During his academic training and early in his career, Lima de Freitas revealed himself as an artist and a critic of the Estado Novo (Dictatorship), was an astute observer of the human condition, which enables one to contextualize his work within a turbulent time, challenging the existing system, during the 1940's and 50's.

"Engaged" in Portuguese neo-realism, the fist works of Lima de Freitas reveal, in addition to an intense preoccupation with everyday life and a constant critical attitude and social denunciation, restlessness and a steady demand that will follow throughout his career. The subjects in painting, drawings and writings of his youth reflex were strongly marked 
by Alentejo, its history and its people. In this period the work of Lima de Freitas reflected a return to figurative seat, communicative and critical sense.

The chronological sequence of the multiple practices of Lima de Freitas, including the collaboration with several magazines and newspapers, be it with articles be it with drawings, reveal how in the multifaceted work of Lima de Freitas the word's place unfolds and transforms itself into drawings, illustrations, paintings and writings in a constant interpretation.

The changes felt in his work since 1964, have led him to abandon the neo-realism and slowly adopt a language supported on magical realism, clearly influenced by Almada Negreiros $^{2}$ and reading of Oriental writings. Lima de Freitas deepens this research not only in the field of sacred geometry as well as numerology, searching for the magical and secret 515 number, the mirror number that connects humanity to divinity, embarking the esoteric, such as alchemy and Cabala. Seeking a rigorous system of measurement, proportion and the number who once guided the most glorious civilizations in history, looking for the balances between nature and timeless harmony that rules the man's mind, placing it at the centre this ecosystem.

This study of Pythagorean numerology, the fruitful dialogue between science and tradition will be reflected, inevitably, in his numerous editorial illustrations, where Lima de Freitas combines the essence of the author's message to an unparalleled knowledge and innovation. We can find this connection in Lusíadas's or in D.Quixote de La Mancha's illustrations. Illustrator of more than one hundred national and foreign books, he has demonstrated his unquestionable quality as a designer, his sensitivity as to the interpretation of the word,
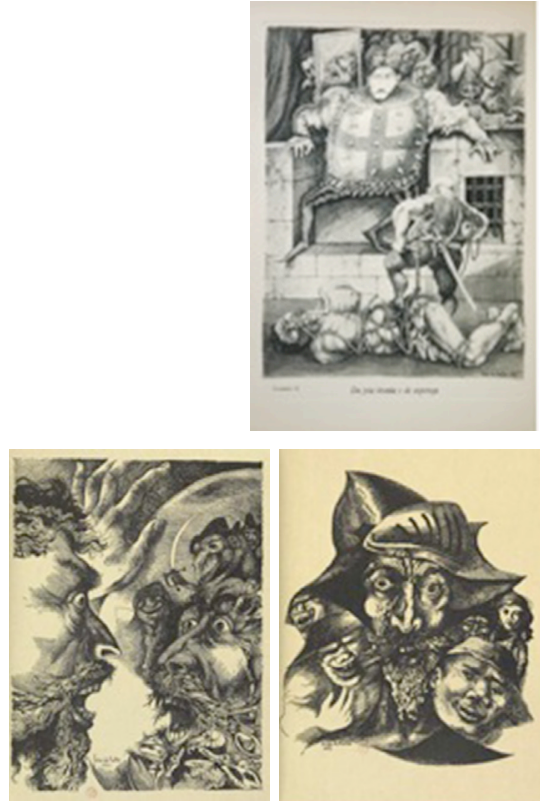

Figure 1.

Lima de Freitas Os Lusíadas from Luís de Camões, R. Artis, 1956.

Figure 2. Lima de Freitas Illustrations for $D$. Quixote, 1953 
theme 2

memory

Figure 3.

Lima de Freitas

Left:, Cover book

Vindima de Sangue de Alves Redol,

(s. d.)

Right:: Cover book

for Argonauta

Collection, 1952 strand 2

design culture

respecting and enhancing with wisdom themes from different portuguese authors such as Luis Vaz de Camões, Fernando Pessoa, Bocage, Cervantes, Herculano, Sá Carneiro, Vergílio Ferreira, Redol Alves, José Guimarães, Almeida Garrett, Aquilino Ribeiro. He also illustrated numerous volumes of English poets and writers in deluxe editions of the Limited Editions Club of New York.

He prefaced, translated and wrote texts, was the author of reference works on Symbolic Numerology, visual and aesthetic semiotics and collaborated in more than a dozen collective works and encyclopedias.

Since 1947 he participated in numerous national and international exhibitions and obtained an international award for Design in Warsaw. He is now represented in private collections and museums in Portugal, Spain, France, Britain, Denmark, Germany, Sweden, Poland, Italy, United States Of America, Brazil, Angola and New Zealand. As of 1946 he has taken part in hundreds of exhibitions and held solo exhibitions mainly in Portugal, France and Denmark, including the major retrospective at the Permanent Aarhus (Denmark), sponsored by the Ceres Foundation, the Society of Fine Arts (Lisbon) and the Museums of Évora and Setubal, his hometown.

Throughout his life, Lima de Freitas has produced book covers of Portuguese and international writers, has drawn stamps, founded the handicraft ceramic in Porches
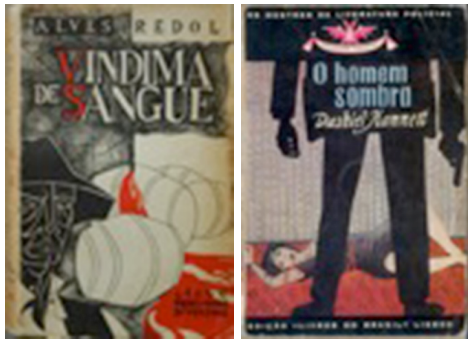

"Algarve" along with the Irish painter Patrick Swift, and the Atelier d'Art et Céramique of Chardenoux in Burgundy. He is the author of numerous pieces of pottery and tile murals that dot Lisbon, where we highlight those of the Rossio train station. He also made some panels in private homes in Oeiras, Trás-os-Montes and New York. He was a member of AICA (Association Internationale des Critiques d'Art - Portuguese Section) and a founding member of the Centre International de Recherches et Études Transdisciplinaires in Paris.

He was a professor of Artistic Training at the Katedralskole in Aarhus, Denmark; Founder and first director of IADE where he taught Drawing, Painting and IADE theoretical disciplines, such as in AR.CO in Lisbon.

\section{Conclusion}

When reflecting on the work of Mestre Lima de Freitas the first conclusion that imposes itself is its multidisciplinary and multifaceted nature, revealing both the incessant search in the field of illustration such as writing and painting, activities he practiced until the end of his life.

If at the beginning of his artistic career early influences reveal strong neo-realist expressions, during the ' 60 s and '70s the search for the other side of the visible, through the study of Eastern and esoteric traditions and opening to other topics such as secret 
geometry led him to embark on the treatment of the human figure both in its natural form as transcendent, progressively absorbing tendencies that were showing up from expressionism to imaginary surrealism.

Man of culture he prefaced and translated many authors, but he himself was the author of reference works on Symbolic Numerology, visual and aesthetic semiotics and collaborated on more than a dozen collective works and encyclopedias. Alongside all these activities and those languages that were born of his painting and his thinking, Lima de Freitas reconciled in an incessant manner the word and image, illustrating over one hundred national and international books.

In art education, he also played an important role as a professor of Art at Katedralskole Aarhus, Denmark in 1964, he was among the founders of IADE between 1969 and 1972, the institution's first principal and was also in the foundation of AR.CO in 1972 (Lisbon).

In his illustrations he not only proved his indisputable quality as a designer, as well as his sensitivity and versatility in the interpretation of the word, respecting and praising with wisdom the themes of both national and international authors. The study of his illustrations and dissemination of the work shown by this author, so rich and multifaceted, will contribute to a deeper knowledge of Portuguese visual culture of the $X X^{\text {th }}$ century.

\section{References}

Brito, Margarida Acciaiuoli de (1991) Os anos 40 em Portugal: o país, o regime e as artes: 'restauração' e 'celebração' (texto policopiado), tese de doutoramento em História da Arte Contemporânea, Universidade Nova de Lisboa.

Côrte-Real, Eduardo (2001) O Triunfo da Virtude, Lisboa: Livros Horizonte.

Durand, Gilbert (1987) Mitolusismos de Lima de Freitas. Sacavém: Co-edição de Perspectivas \& Realidades, Galeria Gilde.

França, José Augusto (1974) A Arte em Portugal no Séc. XX. Lisboa: Bertrand.

Freitas, Lima de (1971).Voz Visível. Lisboa: Ed. Autor.

Freitas, Lima de (1977). Almada e o Número. Lisboa: Arcádia.

Gonçalves, Rui (1986) História de Arte em Portugal. Lisboa: Publicações Alfa, Vol. 13. Mattoso, José (dir.); Rosas, Fernando (dir.) (1994) História de Portugal, o Estado Novo (1926-1974). Lisboa: Circulo de Leitores, 7.o Vol.

Moura, Rita Maia e (2007). O Pensador da Imagem, A llustração na Obra de José Maria Lima de Freitas (1927 -1998). Dissertação de Mestrado. Lisboa: IADE.

Pereira, Fernando António Baptista; (int.) (1997) Lima de Freitas, 50 Anos de Pintura.

Lisboa: Hugin.

Portela, Artur (1982). Salazarismo e Artes Plásticas. Lisboa: Biblioteca Breve - Série

«Artes Plásticas», ICALP.

Sousa, Ernesto de (1961). Lima de Feitas por Ernesto de Sousa. Colecção de Arte

Contemporânea. Lisboa: Ed. Artis, Vol. 10.

Souto, Maria Helena (2009). História do Design em Portugal. Reflexões. Lisboa: Ed. IADE. 